\title{
ШЛЯХИ ФОРМУВАННЯ КУЛЬТУРИ МИРУ І ТОЛЕРАНТНОСТІ У ДІТЕЙ В ЗАКЛАДАХ ЗАГАЛЬНОЇ СЕРЕДНЬОЇ ОСВІТИ В УМОВАХ ВІЙСЬКОВОГО КОНФЛІКТУ В УКРАЇНІ
}

\author{
I. М. Трубавіна \\ д. пед. н., професор, професор кафедри загальної педагогіки та педагогіки вищої школи \\ Харківського національного педагогічного університету імені Г. С. Сковороди
}

В українських школах сьогодні існує буллінг серед дітей, порушення їх прав іншими дітьми внаслідок буллінгу та всіх його форм. Відзначимо, що проблема існування буллінгу в школах є актуальною для багатьох країн, про що свідчить доклад ЮНЕСКО [20], це характерно у т.ч. для України. Таким чином, більшість дітей шкільного віку потерпає від жорстокості, насильства, буллінгу, порушень своїх прав внаслідок цього, діти в шкільному середовищі стикаються в повсякденному житті з тією чи іншою дискримінацією, бачить перемогу культури війни і сили. Враховуючи наявність військового конфлікту на Сході країни, більше, ніж 1600000 внутрішньо переміщених осіб внаслідок цього, серед яких нестачі ресурсів у приймаючих громадах, ризик формування культури війни зростає. «Діти, які були свідками військового конфлікту, що вирішується за допомогою сили і зброї, бачать, що виживає той, хто сильніше і має зброю. Це продукує насильство і ненависть, досвіду яких діти набувають в своєму середовищі і в подальшому переносять на дорослий світ. Виникає ланцюг насильства і вирішення проблем силою, що не є ознакою цивілізованого суспільства, яке прагне до мирного життя і співіснування» [11, с. 4]. Вважаємо, що причинами існування культури війни в світовому середовищі є: проблеми соціалізації дітей, матеріальні проблеми їх сімей, різні ідеологічні погляди, невміння вирішувати конфлікти мирними способами. При цьому проблеми поведінки дітей в школі внаслідок військового конфлікту притаманні лише країнам, де він проходить. Відзначимо, що проблеми протидії буллінгу певною мірою досліджені в науковому товаристві [1; 8 та інші]. Ці дослідження розкривають види, сутність, масштаб буллінгу в дитячому середовищі, шляхи протидії йому. Формування толерантності у дітей певною мірою розкривалося в наукових дослідженнях і методичних посібниках, тренінгах для дітей — в аспекті міжетнічних проблем, поваги до прав дитини. Але ці дослідження були не в умовах військового конфлікту. Існують методичні рекомендації з проблеми [11]. Тому формування культури миру і толерантності у дітей слід починати з визначення теперішніх їх проблем і визначення шляхів їх вирішення.

Метою дослідження є визначення причин буллінгу і культури війни, відсутності культури миру і толерантності у дітей в закладах середньої освіти і визначення шляхів їх формування. Спершу зазначимо, що проблеми жертв буллінгу і тих, хто його здійснює, мають спільне коріння в умовах військового конфлікту. Так, якщо діти стали свідками військових дій, вони набувають трагічного досвіду, який деформує свідомость, цінності і ставлення до людей і миру, у них спостерігаються перебіги настрою, немотивована агресія, постійний страх і очікування повтору військових дій [9]. Переважна більшість дітей відчувала стрес відразу після травматичної події (незначний $48 \%$ та значний $20 \%$ ). $41 \%$ дітей переживали страх, 30 \% - сум, $16 \%$ - злість. 21 \% дітей вказували на проблеми з концентрацією та проблемами зі сном, 17 \% дітей вказували на нічні кошмари. 7 \% дітей зазначали, що після травматичної події не хотіли ні з ким про це говорити та нікого бачити і $15 \%$ - що нічого не хотілось робити» [9]. Це означає, що ці проблеми можуть викликати неадекватні реакції у дітей на зовнішні подражчики, приводити до вибухів в поведінці через багато часу, до нерозуміння поведінки однолітків, до неврозів, неуважності тощо. Відзначимо, що ці проблеми можуть приводити як до прояву буллінгу, так і до того, що дитина може зламатися і стати жертвою буллінгу. Це означає, що роботу з формування культури миру і толерантності в освітньому середовищі слід проводити як спільну з усіма дітьми, так і відмінну щодо причин поведінки жертви чи агресора. I це повинні бути всі діти: як діти ВПО, так і діти з приймаючих громад, діти воїнів АТО, діти з заможних сімей та діти з бідних родин тощо.

Сьогодні в Україні нараховують 16,5 \% дітей від всієї кількості внутрішньо переміщених осіб — це 169408 дітей [5]. Відзначимо, що будь-яка ситуація переміщення викликає проблеми адаптації і кризу сім’ї, яка позначається на дітях $[3 ; 5 ; 15]$. Це спричиняє зростання рівня тривожності, страху, а також актуалізує негативні почуття: тривогу, страхи, фобії, психосоматичні розлади тощо [14; 13]. Це може також виражатися в агресії і буллінгу, неадекватній поведінці. До того ж важкі та тривалі психологічні травми викликають порушення особистісного розвитку: низька самооцінка, порушення міжособистісних стосунків (в тому числі подружніх та батьківства) у дорослому віці $[13 ; 15]$. Маємо тривалі наслідки бачення культури війни. Існують і специфічні проблеми дітей з числа ВПО. За даними ВООЗ, станом на 1.05.2015 року від війни на Донбасі 176 дітей отримали поранення [2]. Це - медико-соціальні проблеми. Врахуємо, що основними причинами внутрішньо- 
го переміщення сімей з дітьми є прагнення безпеки, нестача їжі, води, ліків, військові дії, бомбардування тощо - незадоволення базових потреб і порушення основних прав людини. Тому варто, перш за все, їх відновити і забезпечити реалізацію, усунути умови, які заважають їм реалізуватися. Нереалізація прав дітей і їх порушення перешкоджають формуванню культури миру і толерантності у дітей. І задовольнити їх всі на лінії фронту неможливо. А в прифронтовій зоні, де є маса внутрішньо переміщених людей, спостерігається нестача всіх ресурсів приймаючих громад. Тому діти з числа ВПО і місцеві мешканці громади часто страждають від незадоволення базових потреб, що може бути причиною знущання, буллінгу, ворожнечі. На основі викладеного можемо узагальнити проблеми дітей, які провокують буллінг і освітньому середовищі: психологічні, матеріально-економічні, соціальні, медичні, правові, педагогічні. 3 цим працівники освіти не стикалися в мирних умовах раніше. І всі їх в закладі освіти не можливо вирішити, але треба знати про них, вивчати їх і прагнути до співпраці установ в інтересах дітей і формування в них культури миру і толерантності, задоволення прав і потреб дітей.

Узагальнимо також існуючі сьогодні в Україні причини проблем, які призводять до буллінгу, агресії, культури війни у дітей в закладах середньої освіти: 1) зовнішні (військовий конфлікт в країні, численні переміщення сімей, нестача ресурсів в приймаючих громадах і бідність, соціальна напруженість, відсутність власного житла і скупченість проживання сімей, особливо в місцях компактного проживання внутрішньо переміщених осіб, конфлікти внаслідок цього, відсутність культури миру і толерантності в середовищі як зразка поведінки, відсутність пропаганди і цілеспрямованого формування культури миру і толерантності в суспільстві і мікросередовищі, натомість, пропагування культу сили в ЗМI, розшарування суспільства на бідних і багатих, соціальна і гуманітарна криза в суспільстві, зниження рівня доходів населення, нехтування правами людини і правами дітей в окремих випадках, наявність різних молодіжних субкультур, різна мова тощо) та 2) внутрішні (агресивні установки в свідомості дітей, викривлені цінності їх референтної групи, бажання проявити себе в дитячому середовищі шляхом девіантних вчинків, дитяча образа, бажання самоствердитися за рахунок приниження інших, відсутність поваги до інших, їх прав і свобод, невміння враховувати чужі думки і вирішувати конфлікти мирними способами, відчуття провини за неспроможність батьків вирішити проблеми на новому місці проживання тощо).

Знов-таки, всі їх в закладі середньої освіти не можливо вирішити, але можна в педагогічній площині знайти шляхи вирішення проблем і певною мірою усунути їх причини, нейтралізувати їх вплив. В закладах середньої освіти визначені проблеми буллінгу дітей в умовах військового конфлікту та їх причини можна подолати через створення дитячого освітнього середовища, дружнього до дітей, формування у них культури миру і толерантності як зразка поведінки, що попереджає та усуває конфлікти і агресію, застосування медіації в дитячих конфліктах, залучення дітей до вирішення їх проблем через їх же активну участь, обмеження доступу дітей до контенту з пропагандою насильства і ненависті, розпалювання ворожнечі, повернення дітей до дитинства і роботу педагогів з батьками щодо формування батьківства, батьківської відповідальності за дітей, наснаження батьків на вирішення власних проблем і співпраці зі школою в інтересах майбутнього дітей і задоволення їх прав. Успішна адаптація дітей внутрішньо переміщених осіб, інтеграція їх в нове соціальне і освітнє середовище буде сприяти подоланню насильства, агресії, війни і нетолерантності. Є необхідність щоденної роботи батьків і вчителів над проблемами соціалізації дітей, об'єктивному відображенні подій у їх свідомості, постійній корекційній і виховній роботі з ними.

Зазначимо, що існуючі дослідження розкривають [2; 4; 6; 9-19]: школи, дружні до дитини, їх ознаки; суть культури миру і толерантності, їх виховання; медіацію в школах як засіб вирішення конфліктів в дитячому середовищі, розбудову миру в закладі середньої освіти; профілактику негативних явищ в дитячому освітньому середовищі; батьківську просвіту щодо виховання дітей і прав дітей, взаємодію сім’ї та школи; формування життєвих умінь та навичок у дітей (критичного мислення, комунікативних, прийняття рішень, майстерності управління собою та впливу на інших) роль педагога-миробудівника в формуванні культури миру, його ознаки; щасливе дитяче середовище в закладі освіти; універсальний дизайн як засіб інклюзії та комфорту; корекційну роботу психолога та соціального педагога $з$ дітьми щодо позбавлення причин і проявів агресії, девіантної поведінки; виявлення порушень прав дітей і створення соціальних умов для їх реалізації; інклюзію дітей з особливими потребами; адаптацію дітей з числа ВПО в закладах середньої освіти.

Водночас ці дослідження шляхів подолання буллінгу і формування культури миру і толерантності у дітей не є узагальненими в систему, відсутня цілісна модель роботи в заданому напрямку. Розкриємо на цій основі модель формування культури миру і толерантності у дітей, подолання буллінгу в закладах середньої освіти. При будуванні моделі ми спиралися на компетентнісний, діяльнісний, системний, середовищний, особистісний, аксіологічний, проблемно-орієнтований, родиноцентричний, андрогогічний, культурологічний підходи, підходи до захисту прав людини, теорія участі. 
Мета - формування культури миру і толерантності у дітей, викоренення культури війни, інтолерантності, буллінгу. Завдання педагогічних працівників та адміністрації: 1. протидія негативним явищам (буллінгу, культура війни), викоренення чи обмеження їх причин. 2. робота з формування культури миру і толерантності у дітей створення умов для їх формування. Суб'єкти роботи: батьки, учні, педагоги, адміністрація, громада, працівники НДО та органів місцевого самоврядування. Об'єкти роботи: учні, батьки, педагоги, адміністрація, громада, працівники НДО та органів місцевого самоврядування. Принципи роботи: дитиноцентризму, прав дитини, прав людини, гуманізму, цілісності, індивідуального підходу, родиноцентризму, толерантності, пріоритету загальнолюдських цінностей, стимулювання до самовиховання, виховання в діяльності і спілкуванні, участі дітей. Напрямки роботи: виховний, соціально-педагогічний, психологічний, організаційний, правовий, педагогічний.

Зміст роботи педагогічних працівників і адміністрація закладу середньої освіти: 1) виявлення порушень прав дитини і умов, які цьому сприяють, їх обмеження чи ліквідація, створення умов для реалізації прав дитини; 2) виховання культури миру і толерантності у дітей; 3) корекційна та індивідуальна робота 3 дітьми та їх батьками; 4) створення дружнього для дитини освітнього середовища, включаючи універсальний дизайн, щасливе середовище; 5) підготовка педагогічних працівників до протидії і запобігання буллінгу, культури війни, інтолерантності, до формування культури миру і толерантності; 6) налагодження зв'язків 3 громадою, органами місцевого самоврядування, створення комплексно-цільової програми району щодо формування культури миру і толерантності в громаді і школі; 7) робота з батьками щодо формування культури мирі і толерантності, протидії буллінгу, протидії культурі війни та інтолерантності; 8) створення інклюзивного простору в закладі середньої освіти, адаптація дітей; 9) створення служб медіації і порозуміння в школі, соціально-психолого-педагогічних служб, які працюють за спільним планом і взаємодіють 3 громадою і органами місцевого самоврядування, НДО; 10) створення в школі психологічного клімату, неприйнятного до буллінгу і культури війни, інтолерантності, щасливого освітнього середовища; 11) створення в громаді атмосфери протидії культури війни, пропагування культури миру і толерантності в громаді.

Технології і методики роботи: особистісно-орієнтовані, кризове втручання, допомога для самодопомоги, профілактики негативних явищ в дитячому середовищі, роботи в групах, посередництво, медіації, фасилітації, роботи в парах, колективна творча діяльність, самоосвіта, ігрові технології, діалог культур, програмно-цільове планування роботи, арттерапія, соціодрама тощо.

Умови реалізації моделі роботи формування культури миру і толерантності: організаційні, педагогічні, соціально-педагогічні, психологічні, матеріально-економічні, соціальні, правові.

Результати роботи: виховані в дусі культури миру і толерантності учні, нетерпимість в закладі середньої освіти, громаді, сім’ї до культури війни та інтолерантності, підготовлені до роботи з виховання культури миру і толерантності педагогічні працівники, батьки, які взаємодіють зі школою і громадою в інтересах прав дітей і культури миру. Реалізація моделі можлива за умови застосування комплексно-цільової програми її впровадження, яка визначає терміни, відповідальних за реалізацію.

На основі викладеного можемо говорити про спільні для всіх дітей причини існування та посилення буллінгу в освітньому середовищі, культури війни та інтолерантності в закладах середньої освіти, існування різних причин культури війни в дитячому середовищі: психологічних, педагогічних, соціально-педагогічних, правових, економічних та матеріальних, соціальних. Це вимагає підготовки педагогічних працівників до такої роботи, якої раніше не надавав жодний заклад вищої педагогічної освіти - педагогів не готували до роботи в умовах війни. Є необхідність спільної та диференційованої роботи всіх педагогічних працівників за єдиною моделлю в школі та громаді, яка об’єднує в собі всі напрямки роботи, всіх фахівців в громаді і закладі середньої освіти, включає дітей і батьків в спільну роботу.

\section{Література}

1. Брочковська Ю. Б., Стельмах С. С. (2011). Буллінг як соціально-психологічна проблема // Науковий вісник Львівського державного університету внутрішніх справ, серія Психологія, 2, 145-154. URL: http://nbuv.gov.ua/UJRN/ Nvldu_2011_2_15.

2. Васюник-Кулісва М. (2017). Універсальний дизайн в освіті. URL: http://education-ua.org/ua/articles/938-universalnijdizajn-v-osviti.

3. Діти війни (дослідження проблем дитинства в Україні за умов військової агресії). Український інститут дослідження екстремізму Київ, 2015 р.

4. Дружественная школа. URL: http://zolotievka.ucoz.ru/index/druzhestvennaja_shkola/0-41.

5. Гриневич Л. URL: https://www.ukrinform.ru/rubric-society/2169630-ucitelam-neobhodimo-projti-podgotovku-ctoby-rabotats-uazvimymi-gruppami-detej-grinevic.html.

6. Левченко К. Б., Панок В. Г., Трубавіна І. М. (2016). Розбудова миру. Профілактика і вирішення конфлікту з використанням медіації: соціально-педагогічний аспект. Київ: ФОП Стеценко В. В. 
7. Левченко К. Б., Трубавіна I. М. (2005). Система захисту дітей від жорстокого поводження. Київ: Держсоцслужба.

8. Лушпай Л. (2010). Буллінг як соціально-педагогічна проблема та шляхи ії вирішення (на прикладі досвіду середніх загальноосвітніх шкіл Великої Британії) // Українознавчий альманах. № 4. С. 126-130. URL: http://nbuv.gov.ua/UJRN/ Ukralm_2010_4_29.

9. Магомедов М. Г. Педагогическая поддержка детей с посттравматическими стрессовыми расстройствами в условиях общеобразовательной школы : автореф. дис. ... канд пед. наук 13.00.01. URL: http://www.dissercat.com/content/ pedagogicheskaya-podderzhka-detei-s-posttravmaticheskimi-stressovymi-rasstroistvami-v-uslovi\#ixzz4u4PKxcxx.

10. Матвієнко М. Є. (2017). Підготовка майбутніх учителів початкових класів до формування освітньо-виховного середовища : автореф. дис. ... канд. пед. наук. / ДВНЗ «Донбаський державний педагогічний університет», Слов’янськ, Україна.

11. Михайленко О. Л., Юр'єва К. А, Трубавіна І. М. (2017) Методичні рекомендації до організації факультативних заходів в школах з метою прищеплення гідності, миру та соціального консенсусу. Харків: Планета Принт.

12. Петрочко Ж. В. Концепція школи, дружньої до дитини: основні положення та терміни // Педагогічні науки: теорія, історія, інноваційні технології. 2014. № 2 (36). 84-92.

13. Про спільний проект Дитячого Фонду ЮНІСЕФ, Національного університету «Києво-Могилянська академія» та Українського НМЦ практичної психології і соціальної роботи.

14. Психологічна допомога учасникам АТО та їх сім'ям : колективна монографія / М. І. Мушкевич, Р. П. Федоренко, А. П. Мельник [та ін.] ; за заг. ред. М. І. Мушкевич. Луцьк : Вежа-Друк, 2016. 260 с.

15. Психосоціальна допомога внутрішньо переміщеним дітям, їхнім батькам та сім'ям з дітьми зі Сходу України : посіб. для практиків соціальної сфери / Мельник Л. А. та ін. ; за ред. Волинець Л. С. К. :ТОВ «Видавничий дім «Калита», 2015. $72 \mathrm{c}$.

16. Трубавіна I. М. Концепція програми «Школа, доброжелательная к детям». Розвиток демократії і демократична освіта в Україні: IV Міжнародна конференція, Ялта, 28-30 вересня 2006 р. 2007. С. 473-476.

Трубавіна I. М. Теоретичні основи і сутність школи, дружньої до дитини, як засіб протидії жорстокості і буллінгу в закладах середньої освіти // Вісник Луганського національного університету ім. Тараса Шевченка. Педагогічні науки, березень 2019. № 1 (324) Частина I. С. 117-132.

17. Трубавіна І. М., Левченко К. Б., Тюріна В. О. (2013). Соціальна і корекційна робота з особами, які вчинили насильство в сім’ї / ред. Бандурка О. М., Левченко К. Б., Трубавіна І. М. Т. 1 Київ, Харків.

18. Child friendly schools. URL: https://www.unicef.org/lifeskills/index_7260.html.

19. SchoolViolence and Bullying: Global Status Report Presented at the International Symposium on School Violence and Bullying : From Evidence to Action, Seoul, Republic of Korea,17-19 January 2017. URL: https://www.lucistrust.org/ru/ blog_wgun/sustainable_development_goals_and_the_culture_of_peace. 